\title{
ALGUMAS CONSIDERAÇÕES SOBRE OS SAMBAQUIS FLUVIAIS DO MÉDIO RIBEIRA, SP
}

Em abril de 1993, realizou-se, em caráter emergencial, a exumação de restos esqueletais no sítio Pavão III, um sambaqui fluvial localizado no município de Itaoca, médio vale do Ribeira, sul do Estado de S. Paulo. O sítio em questão não está isolado, e vários outros são conhecidos nesta mesma região do médio Ribeira, tendo sido objeto de um estudo sistemático e abrangente realizado por Cristiana Barreto (1988), do qual provêm as informações de contexto desta nota, e cuja leitura é recomendada aos interessados neste tema.

Estes sítios caracterizam-se por uma espessa camada de carapaças de caramujos terrestres, os (Megalobulimus sp), daí sua designação (concheiros), sendo também chamados de sambaquis fluviais. Esta última designação se deve à sua semelhança com os sambaquis litorâneos. De fato, se por um lado o acúmulo de conchas nestes sítios interioranos nunca apresenta um grande volume que se destaca na topografia circundante, como frequentemente ocorre nos concheiros litorâneos, por outro lado, há outras características que os identificam, como a presença de uma grande quantidade de sepultamentos (sugerindo ocupação prolongada), a presença rarefeita de vestígios faunísticos de origem marinha e ainda certas similitudes nos padrões tecnológicos das indústrias lítica e óssea.

Estas semelhanças, associadas a um padrão de assentamento bastante ligado aos rios de maior porte, levaram Barreto (1988) a sugerir uma conexão das populações dos concheiros do médio Ribeira com aqueles do litoral, sugerindo uma penetração por via fluvial (canoeiros) destas populações no médio vale.

Os trabalhos de campo, realizados em uma área de cerca de $4 \mathrm{~m}^{2}$, evidenciaram restos esqueletais pertencentes a 7 indivíduos: 5 adultos, 1 jovem e 1 criança, em disposição caótica, uns sobre os outros, com exceção de um que estava em conexão anatômica. As características biológicas reveladas nas análises de laboratório apontam para uma baixa estatura e constituição franzina, se comparados aos grupos sambaquieiros do litoral. A análise das patologias dentárias sugere a deficiência de cálcio na dieta, apesar da presença no registro arqueológico de conchas de moluscos e restos de alimentação diversificados como peixes e mamíferos. Além disso, o desgaste central nos dentes indica alimentação rica em fibras de origem vegetal.

Em visita aos laboratórios do MAE, a professora Marília de Mello e Alvim, do Museu Nacional do Rio de Janeiro, teve a oportunidade de examinar esta amostra esqueletal, sobre ela fazendo algumas observações e tecendo alguns comentários. Na observação dos crânios foi detectada a presença de hiperosteose porosa, com lesões localizadas na órbita e principalmente na calvária de um deles, que apresenta o "tipo cicatrizado" na região bregmática. Segundo Mello e Alvim; Uchôa e Gomes (1991), a hiperosteose porosa é uma afecção que atinge principalmente as crianças, causada por verminose em consequência de más condições de higiene aliada à deficiência de ferro na alimentação.

Ainda segundo a referida professora, este grupo difere sensivelmente dos grupos sambaquieiros do litoral, os quais apresentam o crânio bem mais alto, sugerindo que "o homem dos sambaquis fluviais" provavelmente tenha ocupado esta região vindo do interior, não estando relacionado com o "homem do sambaqui do litoral". Naturalmente, tais observações são ainda apenas impressões, baseadas em amostra bastante exígua, e amostras maiores provenientes de pesquisas sistemáticas são essenciais para equacionar corretamente o problema.

De qualquer forma, estamos diante de opiniões divergentes, baseadas em evidências também bastante diferentes, apontando ora para a origem litorânea dos sambaquis fluviais do médio Ribeira, ora para uma proveniência planáltica. Para complicar ainda mais este quadro, G.C. Collet apresenta datas bastante recuadas para um destes concheiros interioranos (em torno de 10.000 anos) que, se confirmadas, remetem a questão para um momento anterior à grande dispersão da cultura sambaquieira pelo litoral sul brasileiro, pelo menos na configuração geomorfológica que hoje conhecemos. 
Tudo isto aponta para o grande interesse arqueológico que suscitam estes sambaquis fluviais do médio vale do Ribeira, situados em plena transição entre os ambientes planáltico e litorâneo. Urge a implementação de um grande projeto de pesquisa sistemática destes sítios, os quais certamente guardam muitas surpresas para a história do povoamento do Brasil meridional.

Pouco tempo depois da visita da Profa. Mello e Alvim ao MAE, tivemos notícia de seu súbito falecimento. Dedicamos assim este pequeno trabalho à sua memória e aos bons momentos que partilhamos.

\section{Referências bibliográficas}

\section{BARRETO, C.N.G.B.}

(1988) A ocupação pré-colonial do vale do Ribeira de Iguape, SP: os sítios concheiros do médio curso. Dissertaçāo de Mestrado, FFLCH-USP.
MELLO e ALVIM, M.C.; UCHÔA, D.P.; GOMES, J.C.O.

(1991) Cribra Orbitalia e lesões cranianas congêneres em populações pré-históricas da costa meridional do Brasil. Rev. do Museu de Arqueologia e Etnologia, 1: 21-53
(*) Museu de Arqueologia e Etnologia da Universidade de São Paulo. Coordenador do Projeto.

(**) Museu de Arqueologia e Etnologia da Universidade de São Paulo.

$(* * *)$ Estagiário do Serviço de Arqueologia do Museu de Arqueologia e Etnologia da Universidade de São Paulo. 